\title{
COMMISSION 41: HISTORY OF ASTRONOMY (HISTOIRE DE L'ASTRONOMIE)
}

\author{
Report of Meetings, 21 and 24 August 1970
}

President: E. Rybka.

SECRETARY: M. A. Hoskin.

After welcoming the 70 members and guests, the President asked those present to stand in memory of the late Aleksander Birkenmajer and A. V. Nielsen.

The following matters were then discussed:

\section{CONSIDERATION OF MEMBERSHIP OF ORGANIZING COMMITTEE}

The Commission approved the proposed names for the new officers of the Commission.

\section{ADOPTION OF REPORT OF COMMISSION 41, REPORT OF THE WORKING GROUP ON ASTRONOMICAL MICROFILMS AND MANUSCRIPTS, AND ANNOUNCEMENT CONCERNING 'JOURNAL FOR THE HISTORY OF ASTRONOMY'}

The Commission Report was approved. Professor Gingerich then reported on the Working Group on Astronomical Microfilms and Manuscripts, citing several important microfilm projects completed or underway, including the Lowell Observatory and the Paris Observatory papers.

Dr. Hoskin, Editor of Journal for the History of Astronomy, announced that in order to cope with the number of suitable papers offered for publication, the journal would appear three times annually from February 1971.

\section{DISCUSSION OF COOPERATION WITH THE INTERNATIONAL UNION FOR THE HISTORY AND PHILOSOPHY OF SCIENCE AND THE INTERNATIONAL UNION OF AMATEUR ASTRONOMERS}

(a) Cooperation with the International Union for the History and Philosophy of Science (IUHPS)

Ways of improving cooperation between Commission 41 and IUHPS were discussed. After it was explained that IUHPS had no Commission structure comparable with that of the IAU, the Commission agreed it would be desirable to invite IUHPS to appoint an additional member of the Organizing Committee of Commission 41, who would become a Consultant of the Commission if not already a member of the IAU. The Commission agreed to recommend this to the General Secretary and the Executive Committee of IAU.

\section{(b) Cooperation with the International Union of Amateur Astronomers (IUAA)}

Commander Derek Howse, Chairman of the Historial Commission of the newly-founded IUAA, invited Commission 41 to forward suggestions to him of useful work which his Historical Commission might undertake. He already intended to offer the services of the National Maritime Museum, Greenwich, as a clearing house for manuscript and other information. Welcoming the creation of the Historical Commission, Professor Rybka suggested liaison might best be effected by Commander Howse's becoming a Consultant of Commission 41. 


\section{CONSIDERATION OF ARRANGEMENTS FOR THE GENERAL HISTORY OF ASTRONOMY}

Professor Rybka reminded the Commission of Resolution No. 4 of the XIII General Assembly endorsing the preparation of such a History, and Professor Gingerich outlined some tentative suggestions which had been made. Cooperation with IUHPS was especially desirable, and there was reason to think the proposal would have warm support from IUHPS. The cooperation might take the form of Commission 41 and IUHPS each appointing five members to an editorial board; such a board would need to meet for a short but intensive working session to thrash out the structure of the History and possible contributions, and arranging for any necessary refereeing might then become the responsibility of the editor, on the advice of the Editorial Board, and a Managing Director might then undertake responsibility for seeing the material through the press. $\operatorname{Dr} M . A$. Hoskin and $D r E$. G. Forbes had tentatively indicated their willingness to act as Editor and Managing Editor respectively.

Dr Whitrow urged that contributions should be issued initially in separate fascicles. Dr Hoskin agreed that this was attractive to contributors, but thought that such a procedure might prove inconvenient to both publishers and booksellers.

Dr Fleckenstein spoke of the need of a single master-mind of the calibre of Cantor if a unified history was to result.

Dr Van't Veer expressed the fear that the emphasis would be on facts rather than interpretation, but the President considered the fear unjustified.

The Commission approved without dissent the actions taken and proposed by the Organizing Committee.

\section{Preparation OF BY-LAWS FOR COMMISSION 41}

The President announced that all Commissions had been asked to prepare By-laws to regulate their own conduct.

\section{DISCUSSION OF ARRANGEMENTS FOR COPERNICAN CELEBRATIONS IN 1973}

The President announced a proposal that Commissions 41 and 47 should sponsor Symposia in Poland in 1973, the 500th anniversary of the birth of Copernicus. This was approved without dissent.

The Commission also noted with approval the possibility of a meeting being arranged by Italian scholars in 1973 in celebration of Copernicus.

\section{DisCUSSION OF KEPLER CELEBRATIONS IN 1971}

Professor Fleckenstein reported on the work of the Kepler Committee founded by IUHPS, in respect of the symposium planned for Leningrad in 1971, the 400th anniversary of the birth of Kepler. He gave a detailed list of speakers and titles arranged by Professor Mikhailov. Professor Fleckenstein explained that of all the celebrations planned, this alone was of truly international character. In particular, contributions would be in various major languages.

\section{Report of Second Meeting}

\section{ANNOUNCEMENTS OF FORTHCOMING MEETINGS AND PUBLICATIONS}

Professor G. Righini announced that the centenary in 1972 of Arcetri Observatory near Florence was to be marked by a meeting, probably in July, to discuss minor figures in the history of astronomy in the 17th, 18th and 19th centuries. The Commission fully supported these proposals.

A catalogue of rare 15th and 16th century astronomical books is being prepared by Signora Giovanna Grassi Conti. The catalogue is at present limited to the libraries of European observatories, 
but it was hoped that it would be possible in the future to extend the range of the catalogue both geographically and to a more recent date.

It was announced that Professor D.J.Price of Yale University is planning a series of facsimile editions of celestial charts, atlases and similar material, to be published by the Theatrum Orbis Terrarum Publishing Company in Amsterdam. Suggestions for possible contributions would be welcomed.

Professor R. B. Berendzen of Boston University is organizing a conference on the education of astronomers to be held in New York beginning 30 August 1971, wherein special reference will be made to the use of material from the history of astronomy.

$D$. J. Schove announced that a conference on eclipses and chronology since 1375 B.C. would be held in London on 6 November 1970.

\section{Scientific Meetings}

The following short papers were presented:

A. Beer: 'The Warburg Museum in Hamburg'.

J. O. Fleckenstein: 'Astronomy in Basle'.

D. J. Schove: 'Sunspot Cycles and the Spectrum of Time'.

Miss $A$. V. Douglas spoke of her research and the consequences of the closing of St. Helena Observatory and Commander Derek Howse described instruments erected at the Royal Navy School Greenwich. 